\title{
Occurrence and Diversity of Nematode Destroying Fungi in Banana Production Zones in Maragua, Kenya
}

\author{
P. M. Wachira ${ }^{1}$, J. W. Kimenju ${ }^{1}$, J. W. Kiarie ${ }^{1}$, A. W. Kihurani ${ }^{2} \&$ S. W. Mwaniki ${ }^{3}$ \\ ${ }^{1}$ University of Nairobi, Nairobi, Kenya \\ ${ }^{2}$ Jomo Kenyatta University of Agriculture and Technology, Nairobi, Kenya \\ ${ }^{3}$ Kenya Agricultural Research Institute, National Agricultural Research Laboratories, Nairobi, Kenya \\ Correspondence: P. M. Wachira, University of Nairobi, Nairobi, Kenya. E-mail: pwachira@uonbi.ac.ke
}

Received: September 25, 2013 Accepted: October 8, 2013 Online Published: November 15, 2013

doi:10.5539/jas.v5n12p180 URL: http://dx.doi.org/10.5539/jas.v5n12p180

\begin{abstract}
The occurrence and diversity of nematode destroying fungi in banana based farming systems was investigated in Maragua, Kenya. The ultimate aim of the study is to harness the potential of these beneficial fungi in the control of plant parasitic nematodes, one of the most important banana pests in the region. The study area was stratified into three agro-ecological zones; high, middle and lower from which soil samples were collected. The soil sprinkle method was used to isolate the nematode destroying fungi from the soil. Fifty eight isolates from five genera and six taxa were identified to species level. The species identified were; Arthrobotrys oligospora, A. dactyloides, Monacrosporium cionopagum, Meria coniospora, Dactyllela lobata and Harposporium aungullilae. The results also indicated that, the occurrence of nematode destroying fungi was significantly $\left(2.2 \times 10^{-16}\right)$ different among the production zones with the frequency of detection decreasing with altitude. The mean frequency of nematode destroying fungi occurrence was 2.8 in the lower zone, while 1.8 and 1.2 was recorded in middle and high zones, respectively. The Shannon diversity index also indicated that, the low ecological zone was the most diverse followed by the middle and the least being the high zone. Monacrosporiun cionopagum was the most frequently isolated of the nematode destroying fungi in the study area with an accumulative frequency of $37.9 \%$. It can be concluded that, soils in the banana production zones are rich in nematode destroying fungi and M. cionopagum is being the most wide spread species.
\end{abstract}

Keywords: biological control, Arthrobotrys spp, plant parasitic nematodes, Monacrosporium cionopagum

\section{Introduction}

Most Kenyan families produce bananas as a staple food crop throughout the year. The area under production has increased significantly from 43,000 hectares in 1996 to 82,000 hectares in 2006. The proportion of land under banana cultivation in Kenya is estimated at $1.7 \%$ of the total arable land, producing an average yield of 14 tons per hectare. The orchards grown using tissue culture plantlets has resulted in an additional income of Sh5.5 billion to the banana farmers over the last 10 years (Mwangi \& Muthoni, 2008). Like in parts of the country, the production of bananas in Maragua is under subsistence farming. The many forms of subsistence and traditional agriculture represent the accumulated experiences of farmers who normally lack access to external inputs, capital, or external scientific knowledge (Bridge, 1996). In 2011, the government earned 23 billion shillings from bananas sold locally, while flowers brought in revenue of 40 billion shillings. Compared with other fruits, bananas are the number one income earner, only second to flowers.

Although banana cultivation plays a significant role in the provision of food security, a progressive decline in yield has been reported worldwide. Likewise, although banana in Kenya provides much-needed household income for small-scale farming families, its potential is yet to be fully tapped. Several causes for the decline have been suggested including; pests, diseases, poor farmer management practices and decline in soil fertility (Waele \& Elsen, 2007). Among the major pests of bananas, plant-parasitic nematodes are very important. Plant-parasitic nematodes are tiny worms that live mainly in soil and roots. In the case of banana plants, the most damaging species spend most of their life cycle in root and corm tissues. Their proliferation disrupts nutrient and water uptake, delay growth and cause banana plants to topple over (Riséde et al., 2010). 
Plant-parasitic nematodes cause extensive damage and substantial yield losses in banana like any other crop (De Waele \& Elsen, 2007). Studies have demonstrated a general lack of awareness of plant-parasitic nematodes by farmers (Talwana et al., 2005). Apart from the direct losses through toppling of affected plants, root damage by nematodes results in slow sucker formation, delayed fruiting, smaller fruit and reduced bunch weight, and a shortened plant life. The nematode problem is even more compounded in vegetable farms which are sometimes intercropped with bananas (Siddiqi, 2000; Kaskavalci, 2007; Ouma, 2009). The control of plant parasitic nematodes becomes therefore very important if the country is to realize the full potential of the banana crop. For decades, the control of plant-parasitic nematodes in agricultural fields has mainly depended on chemical nematicides (Akhtar \& Malik, 2000). This is because the nematicides are efficient and fast-acting (Ooi, 2005). On the other hand, application of nematicides has various concerns. For farmers, the most serious drawbacks are the acquisition of pest resistance to the chemicals, secondary pest outbreaks, and health hazards associated with the application of chemicals. For consumers, the main problems are pesticide residues in food and environmental degradation (Ooi, 2005). Because of such concerns, there is a great deal of interest in applying non-pesticide control methods (Pinkerton et al., 2000; Ooi, 2005; Mashela et al., 2008). Among the proposed strategies is the biological control through utilization of natural enemies for plant parasitic nematodes. These are micro fungi that naturally capture, kill and digest nematodes (Rodrigues et al., 2001; Nordbring-Hertz et al., 2002). They have been proposed as a good candidate for the control of plant parasitic nematodes (Masoomeh et al., 2004; Wachira et al., 2008). Some groups of fungi have previously been utilized in the management of soil pests (Olubunmi \& Rajani, 2004). The objective of this study is therefore to determine the natural occurrence of nematode destroying fungi indifferent banana production zones with the ultimate aim of utilizing them in the management of plant parasitic nematodes.

\section{Material and Methods}

The study area was stratified into three agro ecological zones: high, middle and lower agro ecological zones. The banana varieties grown in the area were; 'Valery', 'Gros Michel' and 'Williams'. The higher altitude zone was characterized by mixed farming, combining livestock and crops such as maize and bananas on the same piece of land. Banana is mainly intercropped with wider range of crops including coffee.

The middle zone was characterized by banana, maize and beans intercrop, while banana was grown as a mono-crop in the lower zone. The most commonly grown banana varieties are; 'Giant cavedish Williams', 'Grande Nine', 'Gros Michel', and other local varieties such as: 'Muraru', and 'Uganda green'. There was a high application of organic manure and specifically cow manure since most of the farmers practiced mixed farming in the lower zone.

Soil samples were taken from ten randomly selected farms in each zone. Each of the farms had a banana orchard which was not less than four years old. From each banana orchard, eight soil samples were collected from at least five meters apart and spreading to at least an area of 50 square meters. The eight soil samples were then mixed together to form a composite sample from which a $500 \mathrm{~g}$ sub samples were taken. The soil samples were placed in a cool box and transported to the laboratory for analysis.

The soil sprinkle technique described by Jaffee et al. (1996) was used to isolate NF from the soil. Tap water agar was prepared by dissolving 20 grams of agar in one liter of tap water. The medium was autoclaved and cooled to $45^{\circ} \mathrm{C}$ before amending it with $0.1 \mathrm{~g} / \mathrm{L}$ of streptomycin sulfate to suppress bacterial growth. Approximately one gram of soil from each sampling point was sprinkled onto the surface of water agar in Petri dishes. A pure culture of plant parasitic nematodes (about 500 Meloidogyne juveniles) was added into the Petri dish as baits. The plates were incubated at room temperature and observed daily under a microscope at low magnification, from the $3^{\text {rd }}$ up to the $6^{\text {th }}$ week. The examinations were focused on trapped nematodes, trapping organs and conidia of the nematode destroying fungi that grew from the soil. After the sixth week, all the fungal colonies that had emerged were sub-cultured on potato dextrose agar (PDA) to obtain pure cultures. Identification was carried as according to the key described by Cook and Godfrey (1964). The mean occurrence, diversity and frequency of isolation of nematode destroying fungi from each agro ecological zone was compared using frequency of occurrence, evenness, Renyi profiles and the Shannon diversity index (Kindt \& Coe, 2005).

\section{Results}

Fifty eight isolates of nematode destroying fungi, distributed in five genera and six taxa were identified in this study (Table 1). The species identified were, Arthrobotrys oligospora (Fresen), A. dactyloides (Drechsler), Monacropsporium cionopagum (Subramanian), Meria coniospora (Drechsler), Dactyllela lobata (Duddington) and Harposporium aungullilae (Lohde). The results also indicated that, the occurrence of nematode destroying fungi was significantly $\left(\mathrm{P}=2.2 \times 10^{-16}\right)$ affected by the ecological zone with the frequency of occurrence 
decreasing with altitude. The lower zone had a mean occurrence of nematode destroying fungi of 2.8 , with 1.8 and 1.2 being recorded in middle and high zones, respectively (Figure 1). The lower zone represented $48.3 \%$ of the total nematode destroying fungi. Out of all the isolates obtained, $48.3 \%$ were from the lower zone.

Table 1. Frequency of nematode destroying fungi isolations in soil samples obtained from banana production zones in Maragua

\begin{tabular}{lcccc}
\hline Species & Rank & Proportion & Proportion & Cumulative frequency \\
\hline M.cionopagum & 1 & 22 & 37.9 & 37.9 \\
A. oligospora & 2 & 14 & 24.1 & 62.1 \\
A. dactyloides & 3 & 9 & 15.5 & 77.6 \\
M. coniospora & 4 & 7 & 12.1 & 89.7 \\
D. lobata & 5 & 5 & 8.6 & 98.3 \\
H. aungullilae & 6 & 1 & 1.7 & 100.0 \\
\hline
\end{tabular}
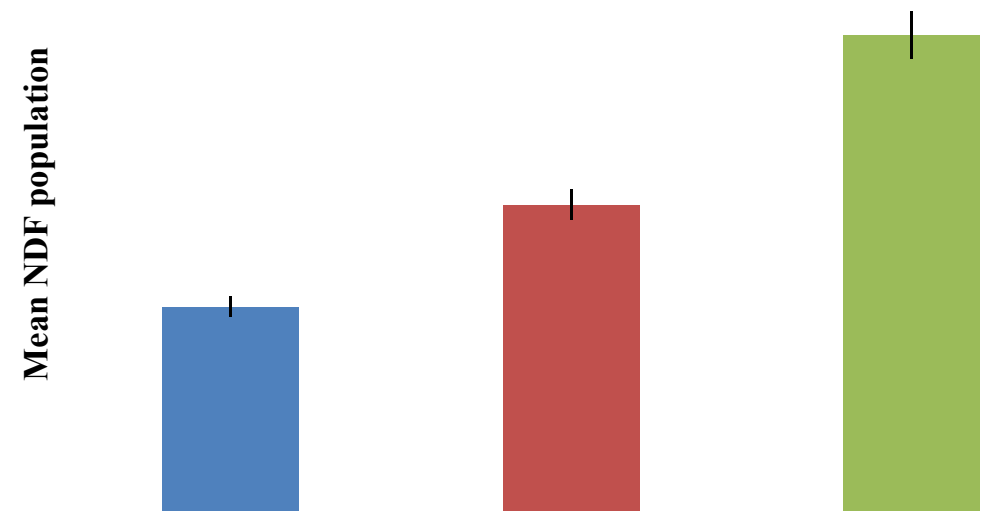

\section{Agroecological Zone}

Figure 1. Occurrence of nematode destroying fungi in different banana production zones in Maragua

Monacrosporium cionopagum was the most frequently isolated species of nematode destroying fungi with a frequency of 37.9, while Harposporium aungulliale was the least encountered with a frequency of 1.7 (Table 1).

All the nematode destroying fungi were significantly affected by the ecological zone (Table 2).

Table 2. Occurrence of different species of nematode destroying fungi in banana growing zones in Maragaua District

\begin{tabular}{lllllll}
\hline Zone & $\begin{array}{l}\text { Monacrosporium } \\
\text { cionopgum }\end{array}$ & $\begin{array}{l}\text { Arthrobotrys } \\
\text { oligospora }\end{array}$ & $\begin{array}{l}\text { Arthobotrys } \\
\text { dactyloides }\end{array}$ & $\begin{array}{l}\text { Dactyllela } \\
\text { lobata }\end{array}$ & $\begin{array}{l}\text { Harposporium } \\
\text { aungullilae }\end{array}$ & $\begin{array}{l}\text { Meria } \\
\text { coniospora }\end{array}$ \\
\hline Low & 1.0 & 0.4 & 0.4 & 0.4 & 0.1 & 0.5 \\
Medium & 0.5 & 0.7 & 0.4 & 0.1 & 0.0 & 0.1 \\
High & 0.7 & 0.3 & 0.1 & 0.0 & 0.0 & 0.1 \\
P.value & $2.2 \times 10^{-16}$ & $2.2 \times 10^{-16}$ & $1.4 \times 10^{-15}$ & $2.1 \times 10^{-12}$ & $1.6 \times 10^{-4}$ & $1.8^{-14}$ \\
\hline
\end{tabular}


The diversity of nematode destroying fungi was higher in the highest UM with a mean Shannon diversity of 0.970, followed by middle zone with 0.636 and the least being the high zone with 0.277 . The same trend was recorded for species richness (Figure 2).

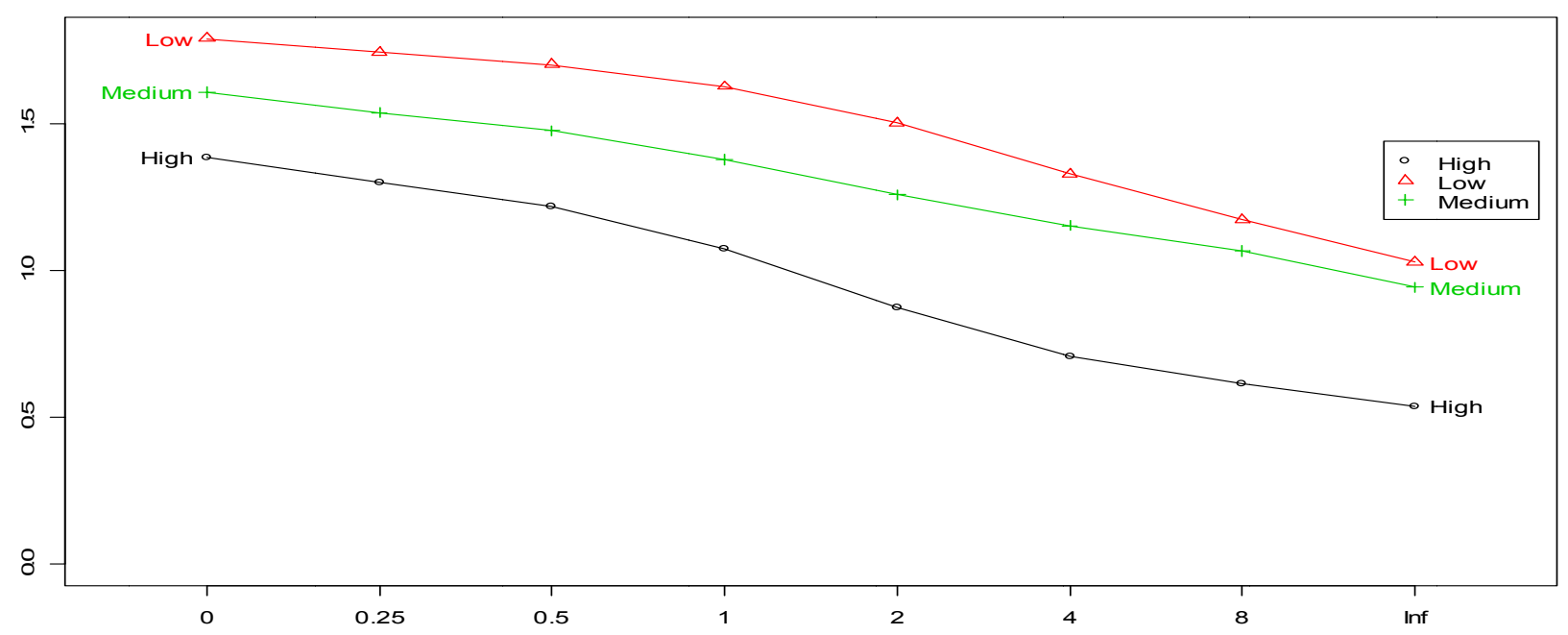

Figure 2. Renyi diversity profile for species of nematode destroying fungi isolated from banana production zones in Maragua

From this study, the area rich in nematode destroying fungi with Monacropsoriun cionopagum being the most wide spread. The total species cumulative curve indicated that, samples used for this study were adequate for estimation of nematode destroying fungi in this study area (Figure 3).



Figure 3. Frequency cummalative curve for the specis of nematode destroying fungi isolated from banana production zones in Maragua

\section{Discussion}

The study has revealed that, nematode destroying fungi are widely distributed in the three ecological zones with the lower zone (UM) harboring the most, followed by the middle zone and the least found in the high zone. This finding is consistent with previous studies which reported that, the fungi are widely distributed although in different densities and diversity across land use systems (Wachira et al., 2008). The finding is of important given the prospect of utilizing them in the management of plant parasitic nematodes which are widespread in agricultural fields (Mukerji \& Ciancio, 2009). Unlike other studies conducted on nematode destroying fungi which have reported Arthrobtrys oligospora to be the most distributed fungus (Jeffee \& Strong, 2005), 
Monacropsporium cionopagum was the most frequently encountered species with a frequency of $37.9 \%$. It was not clear why this was the dominant species.

The lower zone had high diversity and population of nematode destroying fungi. This could be explained by the management practices of this zone where there was a heavy application of organic manure on the farms. Organic amendments are known to stimulate the frequency and diversity of soil biodiversity. It is thought that, the organic amendments increase the biological activity of the soil thereby stimulating the beneficial soil microorganism including the nematode destroying fungi (Wachira et al., 2009). This on the other hand, is thought to decrease the population of plant parasitic nematodes in the soil. This is supported by the findings of Timm et al. (2001) who suggested that, the increase in nematode-trapping fungi after addition of organic amendment is due to available carbon and energy from the organic amendment and nitrogen from consumed nematodes. In a related study, Jaffee (2006) also showed that, organic amendments enhanced build-up of nematode-trapping fungi, Dactylellina candidum (Nees) and are thought to be influenced differently depending on their feeding mechanism (parasitic or saprophytic).

From this study, intercropping bananas with other crops was seen to affect the occurrence and diversity of nematode destroying fungi. This was observed in the higher zone where the least number (12) of nematode destroying fungi was recorded. The zone was characterized with intercrop of bananas with other crops, especially maize, beans and coffee. In a related study, banana intercropping was reported to have an effect on soil biodiversity. When it was intercropped with sweet potatoes, the incidence of the root lesion nematode (Pratylenctius goodey) was reduced in heavily infected banana plants around Lake Victoria (Ouma, 2009). In this study, this observation could be attributed to the effect of chemical fertilizers applied to the intercrops. Chemical fertilizers have been reported to affect soil biodiversity and specifically reduce the chances of isolating nematode destroying fungi (Duponnois et al., 2001). Intercropping could reduce management inputs and result in sustainable systems that more effectively use and even potentially replenish natural resources used during crop production for long term management of farmland. Unfortunately, in intercropping, there is a competition between the plants for light, water and soil nutrients leading to reduced yield. This competition can also lead to pest and diseases susceptibility. Therefore agricultural practices that use high amounts of external-inputs, such as inorganic fertilizers, pesticides, and other amendments can overcome specific soil constraints to crop production. However, especially in the most intensively managed systems, this has resulted in continuous environmental degradation, particularly of soil, vegetation and water resources and decline of soil organic matter levels (Singh, 2000). Concerning mineral fertilizer application, it has been observed that, high inputs tend to lead to lower biodiversity.

The middle zone was the transitional zone, between the cold and warm weather conditions. It was characterized with well managed banana crop with less intercropping compared to the higher zone. There was limited application of chemical fertilizers' compared to the higher zone since many farmers opted for banana monoculture. Application of organic amendments especially the cow manure was higher in this zone compared to the higher zones.

In conclusion, it has been established that, the diversity and occurrence of nematode destroying fungi is significantly influenced by the agro ecological zone in which bananas are grown. This is could be a result from management practices adopted by growers as the environmental factors. More work is needed to elucidate the potential of the fungi in nematode management.

\section{Reference}

Akhtar, M., \& Malik, A. (2000). Roles of organic soil amendments and soil organisms in the biological control of plant parasitic-nematodes: a review. Bioresource Technology, 74(1), 35-47. http://dx.doi.org/10.1016/S0960-8524(99)00154-6

Bridge, J. (1996). Nematode management in sustainable and subsistence Agriculture. Annu. Rev. Phytopathol, 34, 201-225. http://dx.doi.org/10.1146/annurev.phyto.34.1.201

Cooke, R. C., \& Godfrey, B. E. S. (1964). A key to the nematode-destroying fungi. Transactions of the British Mycological Society, 47, 61-74. http://dx.doi.org/10.1016/S0007-1536(64)80081-4

De Waele, D., \& Elsen. A. (2007). Challenges in Tropical Plant Nematology. Annual Review Phytopathology, 45, 457-85. http://dx.doi.org/10.1146/annurev.phyto.45.062806.094438

Duponnois, R., Chotte, J. L., Sall, S., \& Cadet, P. (2001). The effects of organic amendments on the interactions between a nematophagous fungus Arthrobotrys oligospsora and the root-knot nematode Meloidogyne 
mayaguensis parasitizing tomato plants. Biology and Fertility of Soils, 34, 1-6. http://dx.doi.org/10.1007/s003740100344

Jaffee, B. A. (1996). Soil Microcosms and the population biology of Nematophagous fungi. Ecology, 77, 690-693. http://dx.doi.org/10.2307/2265493

Jaffee, B. A., \& Strong, D. R. (2005). Strong bottom-up and weak top-down effects in soil: nematode-parasitized insects and nematode-trapping fungi. Soil Biology and Biochemistry, 37, 1011-1021. http://dx.doi.org/10.1016/j.soilbio.2004.05.026

Kaşkavalci, G. (2007). Effects of Soil Solarization and Organic Amendment Treatments for Controlling Meloidogyne incognita in Tomato cultivars in Western Anatolia. Turk. J. Agric. For, 31,159-167.

Kindt, R., \& Coe, R. (2005). Tree diversity analysis. A manual and software for common statistical methods for ecological and biodiversity studies. Nairobi: World Agro-forestry Center (ICRAF). Retrieved from http://www.worldagroforestry.org/library/listdetails.asp?id=46934

Mashela, P., Mokgalong, N., De Waele, D., \& McDonald, A. (2008). Effect of Lippia javanica organic amendment on suppression of Meloidogyne incognita and tomato growth and yield in micro plots. African Plant Protection, 16, 1-6.

Masoomeh, S. G., Mehdi, R. A., Sharokh, R. B., Ali, E. R. Z., \& Majid, E. (2004). Screening of soil and sheep faecal samples for predacious fungi: Isolation and characterization of the nematode-trapping fungus Arthrobotrys oligospora. Iranian Biomedical Journal, 8(3), 135-142.

Mukerji, K. G., \& Ciancio, A. (2009). Integrated Management of Banana Nematodes. In Integrated management of fruit crops and forest nematodes (pp. 3-61).

Mwangi, M., \& Muthoni, S. (2008). Implementing banana macro-propagation in Kenya - Potential and Challenges. Proceedings of the $1^{\text {st }}$ International Conference on Agricultural Biosciences 2008. Book of Abstracts: Volume $\quad 1 . \quad$ Agriculture/IeCAB-2008-Abstracts-Volume1. Retrieved from http://www.e-conference.elewa.org/agriculture

Nordbring-Hertz, B., Jansson, H. B., \& Tunlid, A. (2006). Nematophagous Fungi in Encyclopedia of Life Sciences. John Wiley \& Sons, Ltd.

Olubunmi, O. F., \& Rajani, S. R. (2004). Biological control of root knot nematodes (Meloidogyne spp.) on tissue culture banana (dwarf cavendish var. basarai). Acta Hort, 635, 183-186.

Ooi, P. A. C. (2005). Non-pesticide methods for controlling diseases and insect pests. Report of the APO Seminar on Non-pesticide Methods for Controlling Diseases and Insect Pests held in Japan, 10-17 April 2002.

Ouma, G. (2009). Intercropping and its application to banana production in East Africa: A review. Journal of Plant Breed. Crop Science, 1, 13-15.

Pinkerton, J. N., Ivors, K. L., Miller, M. L., \& Moore, L. W. (2000). Effect of solarozation and cover crops on populations of selected soil borne plant pathogens in western Oregon. Plant Disease, 84, $952-960$. http://dx.doi.org/10.1094/PDIS.2000.84.9.952

Risède, J. R., Chabrier, C., Dorel, M., Dambas, T., Achard, R., \& Quénéhervé, P. (2010). Integrated management of banana nematodes: Lessons from a case study in the French West Indies. Banana Case Study - Guide Number 4.

Rodrigues, M. L. A., Castro, A. A., Oliveira, C. R. R., Anjos, D. H. S., Bittencourt, V. R. E. P., \& Aranjo, J. V. (2001). Trapping capability of Arthrobotrys sp and Monacrosporium thaumasium on Cyathostome larvae. Revista Brasieira de Parasitologia Veterinaria Agosto, 10, 51-54.

Siddiqi, M. R. (2000). Tylenchida Parasites of Plants and Insects (2nd ed., p. 835). Wallingford, UK: CABI Publishing. CAB International. http://dx.doi.org/10.1079/9780851992020.0000

Singh, R. B. (2000). Environmental consequences of agricultural development: a case study from the Green Revolution state of Haryana, India. Agriculture, Ecosystem and Environment, 82, 97-103. http://dx.doi.org/10.1016/S0167-8809(00)00219-X

Talwana, H. A. L., Speijer, P. R., De Waele, D., \& Swennen, R. L. (2005). Nematode root infection affects nutrient concentrations in banana leaves. African Crop Science Conference Proceedings, 7, 1527-1537.

Timm, L., Pearson, D., \& Jaffee, B. (2001). Nematode-trapping fungi in conventionally and organically managed corn-tomato rotations. Mycologia, 93, 25-29. http://dx.doi.org/10.2307/3761602 
Wachira, P. M, Kimenju, J. W., Okoth, S., Mibey, R. K., \& Mung'atu, J. (2008). Effect of land use on occurrence and diversity of nematode destroying fungi in Taita Taveta, Kenya. Asian Journal of Plant Sciences, 7, 447453. http://dx.doi.org/10.3923/ajps.2008.447.453

Wachira, P. M, Okoth, S., Kimenju, J., \& Mibey, R. K. (2009). Influence of land use and soil management practices on the occurrence of nematode destroying fungi in Taita Taveta, Kenya. Tropical and Subtropical Agro ecosystems, 10, 213-223.

\section{Copyrights}

Copyright for this article is retained by the author(s), with first publication rights granted to the journal.

This is an open-access article distributed under the terms and conditions of the Creative Commons Attribution license (http://creativecommons.org/licenses/by/3.0/). 